\title{
Batch Thermodynamics and Kinetic Study for Removal of Cationic Dye from Aqueous Solution Using Iraqi Limestone
}

\author{
Mohammed Hussein Ali \\ Chemistry Dep. /College of Sciencel AL-Nahrain University
}

\begin{abstract}
Model using Iraqi limestone as an adsorbent has been investigated. The influences of equilibrium time, limestone dosage, limestone particle size, $\mathrm{pH}$ of solution, adsorption isotherms and temperature on adsorption performance have been experimentally verified by a batch method. The adsorbent used in this study exhibited a good adsorption potential at initial $\mathrm{pH} 10$, temperatures $28^{\circ} \mathrm{C}$, particle size $75 \mu \mathrm{m}$, limestone dosage $0.1 \mathrm{~g}$ for equilibrium time $140 \mathrm{~min}$. The removal efficiency and distribution coefficient have also been determined for the adsorption system as a function of dosage of the adsorbent. The experimental results are described by Langmuir and Freundlich isotherm models. Experimental results show that the kinetic model of pseudo-second order provided a good description of the whole experimental data more than the kinetic of the Lagergren-first order.
\end{abstract}

Keyword: Batch adsorption, Methyl Violet, Thermodynamics and Kinetic models.

\section{Introduction}

Dye contaminated wastewater originates from a number of industries, such as textile, metal plating, packaging, and paper industry. The need for the treatment of dye contaminated wastewater arose from the environmental impact. They impart objectionable color on water bodies and retard photosynthesis hence leads the aquatic life on the path of extinction. Some dyes have been found to act as substrate for metal ions and may import contamination by heavy metals [1]. It has also been reported that many dyes and pigments have toxic as well as carcinogenic, mutagenic, and teratogenic effects on aquatic life as well as humans [2,3].

They are water soluble, and are responsible for the blue, red, violet and purple colorations in several plants [4]. Methyl violate dye, which is known to be highly toxic to mammalian cells and to act as a tumors enhancing agent. However, despite the large amount of data on its toxic effects, it is still used in aquaculture and other industries [4], [5]. This dye can be partially or totally purified by adsorption process.

Adsorption of dye at the solid/liquid interface has been extensively studied the last years. One reason for this interest is that importance of adsorption on solid surfaces in many industrial applications in order to improve efficiency and economy. Therefore, it is essential to understand the mechanism and kinetics of adsorption.

Adsorption techniques have proven successful in removing colored organic species with activated carbon being the most widely used adsorbent due to its high capacity for the adsorption of organic materials [67]. However, due to its high cost and the difficulty of regeneration, a search for cheap, effective adsorbents such as Iraqi limestone. Unlike activated carbons, limestone is relatively cheap due to its accessibility and abundance [7]. In recent years, limestone is important in many different fields such as agriculture, oil drilling, and the building industry.

A large variety of non-conventional adsorbent materials have been also proposed and studied for their ability to remove dyes [8]. Therefore, in recent years, many investigators have studied the feasibility of using low cost substances, such as: plum kernels [9], chitin [10], chitosan [11], perlite [12], natural clay [13, 14], bagasse pith [15], fly ash [16, 17], wood [18, 19], rice husk [20] and peat [21, 22].

Thus, this investigation aims at to study kinetics and thermodynamic activation parameters, to describe the rate and mechanism of adsorption, to determine the factors controlling the rate of adsorption and to find out the possibility of using this material as low-cost adsorbent for the removal of dye. The effect of equilibrium time, limestone dosage, limestone particle size, $\mathrm{pH}$ of solution, adsorption isotherms and temperature on methyl violet adsorption rate have been evaluated.

\subsection{Materials:}

\section{Experimental Techniqe}

\subsubsection{Limestone}

Iraqi limestone used in this investigation is brought from Bahr Al-Najaf Area (about $20 \mathrm{~km}$ to the west of Al-Najaf City). It is crushed to the required size by means of laboratorial mechanical crusher .There are huge quantities (about 75 million tons) of limestone is found in Bahr Al-Najaf Area [23, 24]. 
Table (1) shows the chemical composition of limestone, the results represent the average of three samples.

Table 1. Chemical Composition of Limestone

\begin{tabular}{|l|l|}
\hline Oxides & Percentage (\%) \\
\hline Lime $-\mathrm{CaO}$ & 38.90 \\
\hline Silica $-\mathrm{SiO} 2$ & 9.17 \\
\hline Magnesia $-\mathrm{MgO}$ & 5.37 \\
\hline Ferric Oxide $-\mathrm{Fe}$ & $2 \mathrm{O} 31.16$ \\
\hline Alumina $-\mathrm{Al}$ & $2 \mathrm{O} 30.89$ \\
\hline Sulphuric Anhydride $-\mathrm{SO}$ & 30.35 \\
\hline Loss of Ignition (L.O.I) & 43.70 \\
\hline
\end{tabular}

\subsubsection{Methyl violet}

Methyl violet contains a secondary amine group. The color of methyl violet changes from yellow to green in the $\mathrm{pH}$ range $0.13-0.5$, from green to blue in the $\mathrm{Ph}$ range 2.0-3.0. When $\mathrm{pH}$ is higher than 3, the solubility of methyl violet are essentially unchanged. Methyl violet has a molecular weight of $393.96 \mathrm{~g}$ mol_1. The structure of this dye is shown in Fig. 1 [25].<smiles>CNc1ccc(C(=C2C=CC(=[N+](C)C)C=C2)c2ccc(N(C)C)cc2)cc1</smiles>

Fig. 1. The structure of methyl violet.

\subsection{Batch equilibrium time Study}

The experiments were carried out at constant initial concentration, 10, 20 and $30 \mathrm{ppm}$ at constant temperature $\left(28^{\circ} \mathrm{C}\right)$ and agitated at $120 \mathrm{rpm}$. The samples $(1 \mathrm{ml})$ were withdrawn before mixing the adsorbent and the dye bearing solution and at pre-determined time intervals; every 5 minutes for the first 30 minutes and at every 10 minutes for the next 30 minutes. For the next 120 minutes, sampling was in every 30 minutes. For the last 120 minutes, sampling was in every 60 minutes.

\subsection{Effect of limestone dosage}

The effect of limestone dosage on the adsorption process was investigated by varying limestone dosage from $(10,20,30,40,50,60,70,80,90$ and $100 \mathrm{mg}$ per $100 \mathrm{ml})$ in the test solution while keeping the initial dye concentration (10 ppm) constant, at equilibrium times during $140 \mathrm{~min}$.

\subsection{Effect of limestone particle size}

Effect of limestone particle size was investigated by varying limestone particle sizes from $75 \mu \mathrm{m}$ to 350 $\mu \mathrm{m}$. In experiments, a $0.1 \mathrm{~g}$ sample of limestone, add to constant concentration of methyl violate $20 \mathrm{ppm}$ in 100 $\mathrm{ml}$, at equilibrium times during $140 \mathrm{~min}$.

\subsection{The effect of $\mathrm{pH}$ on adsorption process}

Effect of initial $\mathrm{pH}$ was investigated at various $\mathrm{pH}(3-10)$, In the experiments, a $0.1 \mathrm{~g}$ sample of limestone was added to each $100 \mathrm{~mL}$ volume of methyl violate aqueous solution having an initial concentration 20ppm for a constant sorption time, $140 \mathrm{~min}$. 


\subsection{The Batch Adsorption Studies}

The adsorption experiment was carried by adding fixed amount of adsorbent $(0.1 \mathrm{~g})$ into $100 \mathrm{ml}$ of dye standard solution with the range of initial concentration within 5 to $30 \mathrm{ppm}$ (at optimum $\mathrm{pH}$ ), which was put inside the $250 \mathrm{ml}$ conical flask (Pyrex, England). The conical flask with limestone-dye mixture were then covered with aluminum foil to avoid evaporation of dye solution before it being put into the incubator shaker (Cretomat Is) which operated at $120 \mathrm{rpm}$ and with constant temperature $28^{\circ} \mathrm{C}$ until it reach equilibrium.

The amount of dye adsorbed which is also known as adsorption capacity, $Q e(\mathrm{mg} / \mathrm{g})$ can be calculated from equation (1)

$$
Q e=\frac{V(C o-C e)}{m}
$$

Where $C o$ is the initial concentration, $C e$ is the final concentration, $m$ is the mass of adsorbent used and $V$ is the volume of dye solution.

\subsection{Effect of temperature}

A $0.1 \mathrm{~g}$ sample of limestone was added to each $100 \mathrm{~mL}$ volume of methyl violate aqueous solution having an initial concentration $(5,10,15,20,25$, and 30$) \mathrm{ppm}$. The experiments were carried out at 28,48 , and $68{ }^{\circ} \mathrm{C}$ in a constant temperature shaker bath which controlled the temperature to within $\pm 1{ }^{\circ} \mathrm{C}$ for a constant equilibrium time, $140 \mathrm{~min}$.

\subsection{Analysis of Dye}

All the samples were analyzed using UV-Visible spectrophotometer (Genesys 10uv) at maximum wavelength $(\lambda \max )$ of $597 \mathrm{~nm}$.

\subsection{Equilibrium time}

\section{Result And Discution}

Figure 2 represents the variation in methyl violet adsorption on limestone with shaking time at different methyl violet solution concentrations (10,20, and $30 \mathrm{ppm})$. This figure indicates that while the adsorption of methyl violet is quite rapid initially, the rate of adsorption becomes slower with the passage of time and reaches a constant value at $140 \mathrm{~min}$ (equilibrium time). The initial faster rate may be due to the availability of the uncovered surface area of the adsorbents, since the adsorption kinetics depends on the surface area of the adsorbent [26]. It is quite evident from this figure that the percentage adsorption at equilibrium, as well as prior to equilibrium, decreases with an increase in methyl violet concentration.

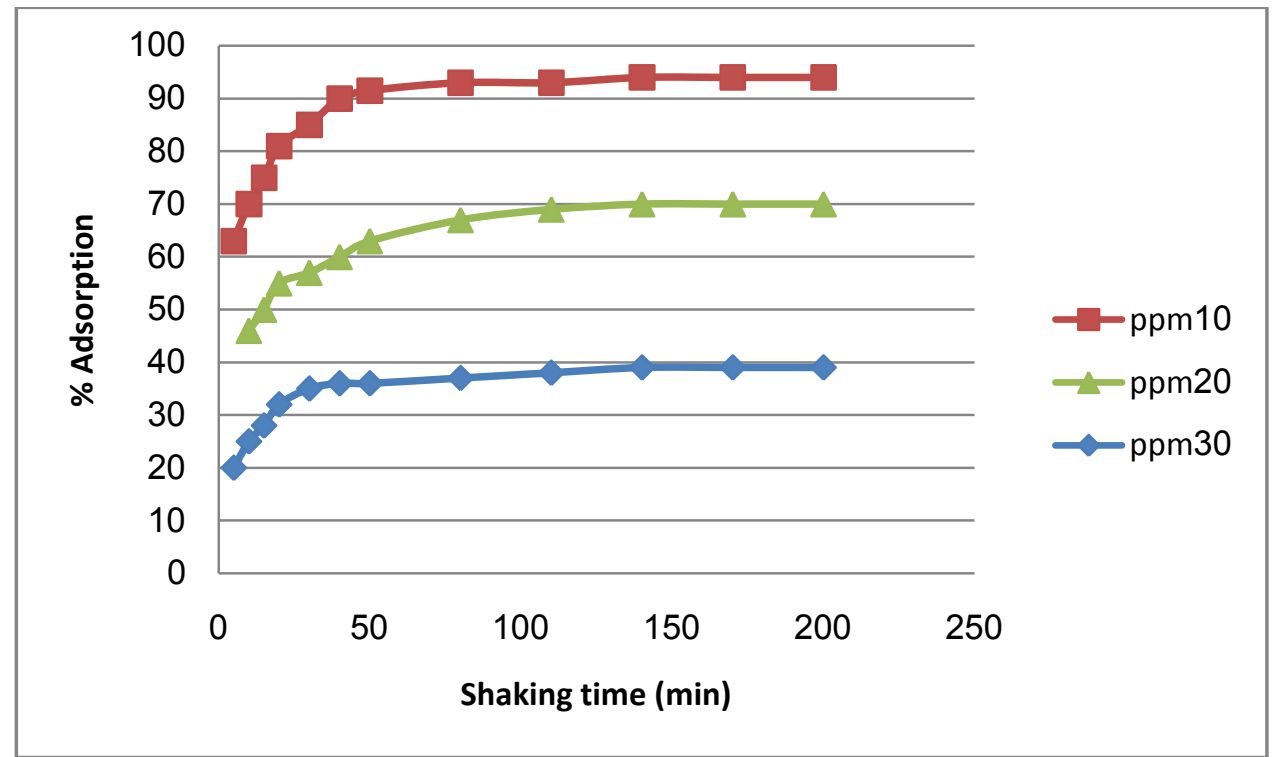

Fig. 2. Variation of $\%$ adsorption with shaking time for the adsorption of methyl violet on limestone from aqueous solutions.

\subsection{Effect of limestone dosage}

The adsorption of methyl violet onto Iraqi limestone was studied by changing the amount of adsorbent $(10,20,30,40,50,60,70,80,90$ and $100 \mathrm{mg}$ per $100 \mathrm{ml})$ in the test solution while keeping the initial dye concentration (10 ppm) constant, at equilibrium times during $140 \mathrm{~min}$ the results are shown in Fig. 3. 


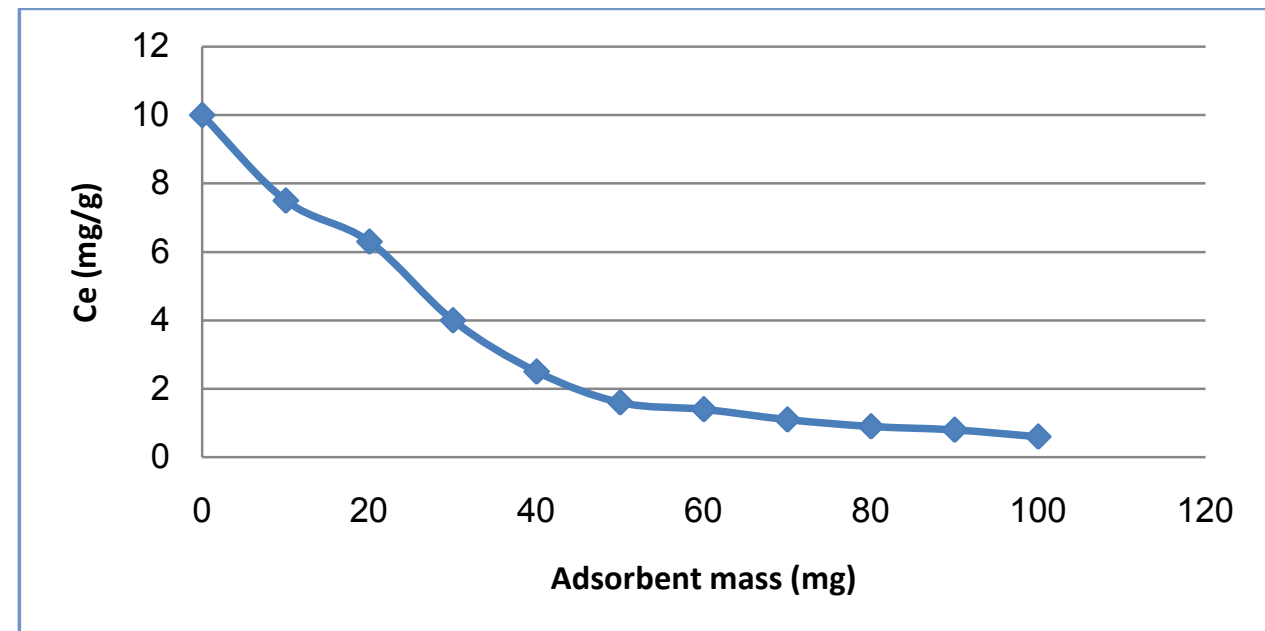

Fig. 3. Effect of adsorbent amount $(10 \mathrm{mg}$, to $100 \mathrm{mg}$, teq $=140 \mathrm{~min})$.on the equilibrium concentration of methyl violet adsorbed onto Iraqi limestone

In the methyl violet removal, it is seen that the adsorption efficiency increases as the limestone amount increases. The increase in the efficiency can be explained by the increasing surface area where the adsorption takes place [17]. As seen in Fig. 3, optimum limestone dosage that can be used in methyl violet removal is 100 $\mathrm{mg}$ (of limestone) per $100 \mathrm{ml}$. Thus, further experiments were carried on by using $100 \mathrm{mg}$ of adsorbent.

\subsection{Effect of limestone particle size}

The experimental results of the adsorption of methyl violet on the Iraqi limestone are reported. Fig. 4 shows the amount adsorbed against a fixed weight $(0.1 \mathrm{~g})$ of different particle sizes of the adsorbent. As the particle size of the adsorbent increased from $75 \mu \mathrm{m}$ to $350 \mu \mathrm{m}$, the adsorbed amount decreased. It was observed that there is a best adsorption as the particle size $75 \mu \mathrm{m}$ is approached. As a result, the particle size of $75 \mu \mathrm{m}$ was used in the subsequent experiments of this work.

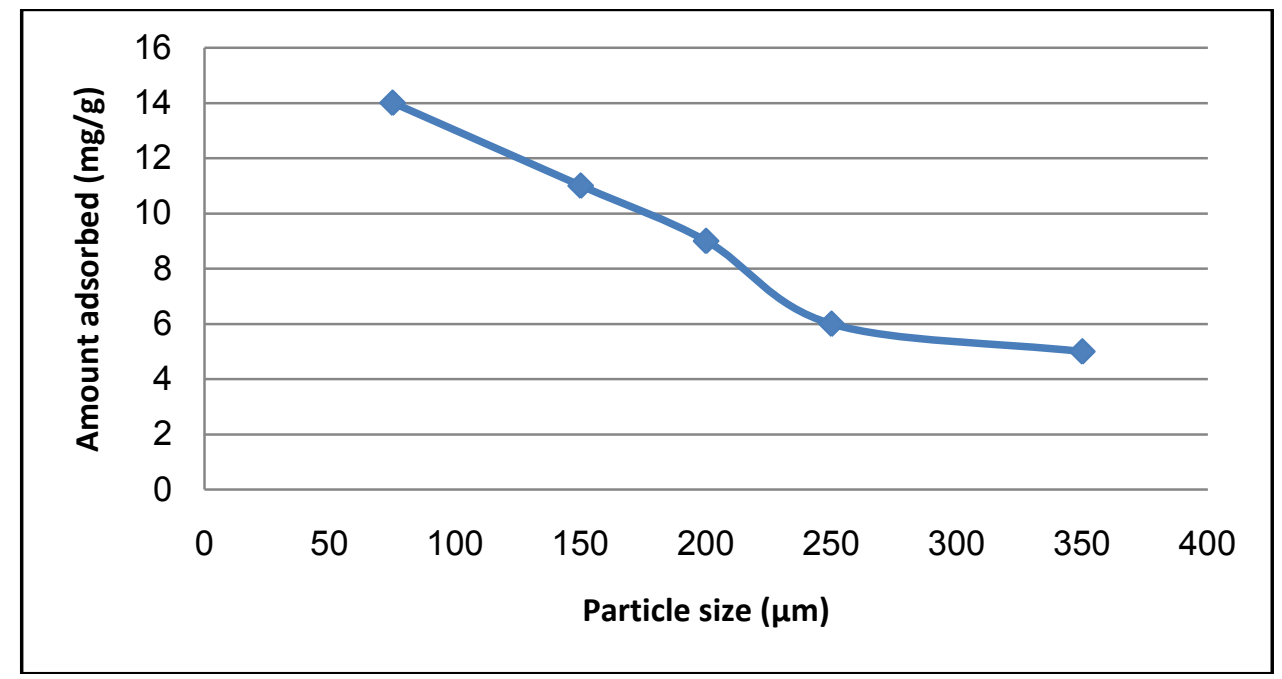

Fig. 4. Amount adsorbed $(\mathrm{mg} / \mathrm{g})$ against particle size $(\mu \mathrm{m})$ for methyl violet adsorption onto Iraqi limestone

\subsection{The effect of $\mathrm{pH}$ on adsorption process}

The magnitude of electrostatic charges imparted by the ionized dye molecules is primarily controlled by the $\mathrm{pH}$ of medium. The amount of dye adsorbed or rate of adsorption tends to vary with $\mathrm{pH}(3-10)$ of aqueous medium. The amount of methyl violet adsorbed on the limestone as a function of $\mathrm{pH}$ at an initial dye concentration of $20 \mathrm{ppm}$ and temperature $28 \mathrm{C}^{\circ}$ is shown in Fig. 5. The amount of methyl violet adsorbed increased with increase in $\mathrm{pH}$ (i.e., as the solution became more basic). The adsorption of methyl violet on limestone increased from $7 \mathrm{mg} / \mathrm{g}$ to $16 \mathrm{mg} / \mathrm{g}$, when $\mathrm{pH}$ was increased from 3 to 10 (Fig. 4) at $28{ }^{\circ} \mathrm{C}$ and $\mathrm{C}_{\mathrm{o}}=20 \mathrm{ppm}$. This indicates that the adsorption capacity of the limestone is $\mathrm{pH}$ dependent. Thus, it is clear that $\mathrm{pH}$ determined the speciation of the methyl violet as well as providing a favorable adsorbent surface charge for the 
adsorption to occur. As the pH increased from 3 to 10, the number of ionizable sites on the limestone increased. These observations are in line with earlier findings of Lafferty and Hobday [27].

$\mathrm{SOH}+\mathrm{OH}^{-}=\mathrm{SO}^{-}+\mathrm{H} 2 \mathrm{O}$

It had been shown that limestone samples had no point of zero charge and exhibited negative zeta potential values in the $\mathrm{pH}$ range $3-11[28,29]$. As the $\mathrm{pH}$ of the dye solution became higher, the association of dye cations with more negatively charged limestone could more easily take place;

$\mathrm{SO}^{-}+\mathrm{Dye}^{+}=\mathrm{S}-\mathrm{O}-\mathrm{Dye}$

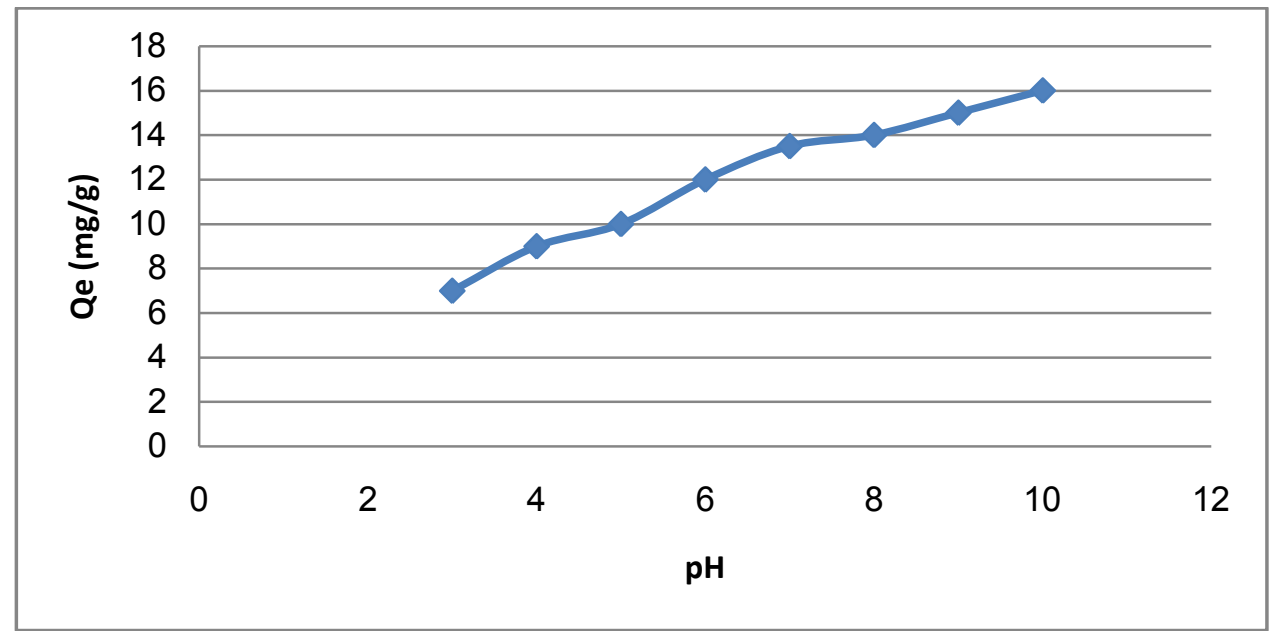

Fig. 5. Amount adsorbed (mg/g) against $\mathrm{pH}$ for methyl violet adsorption onto Iraqi limestone

\subsection{Adsorption isotherms}

In order to optimize the design of an adsorption system to remove basic dyes from effluents, it is important to establish the most appropriate correlation for the equilibrium curves. In this respect, the equilibrium experimental data for adsorbed methyl violet onto Iraqi limestone were compared using two isotherm equations namely, Langmuir, and Freundlich.

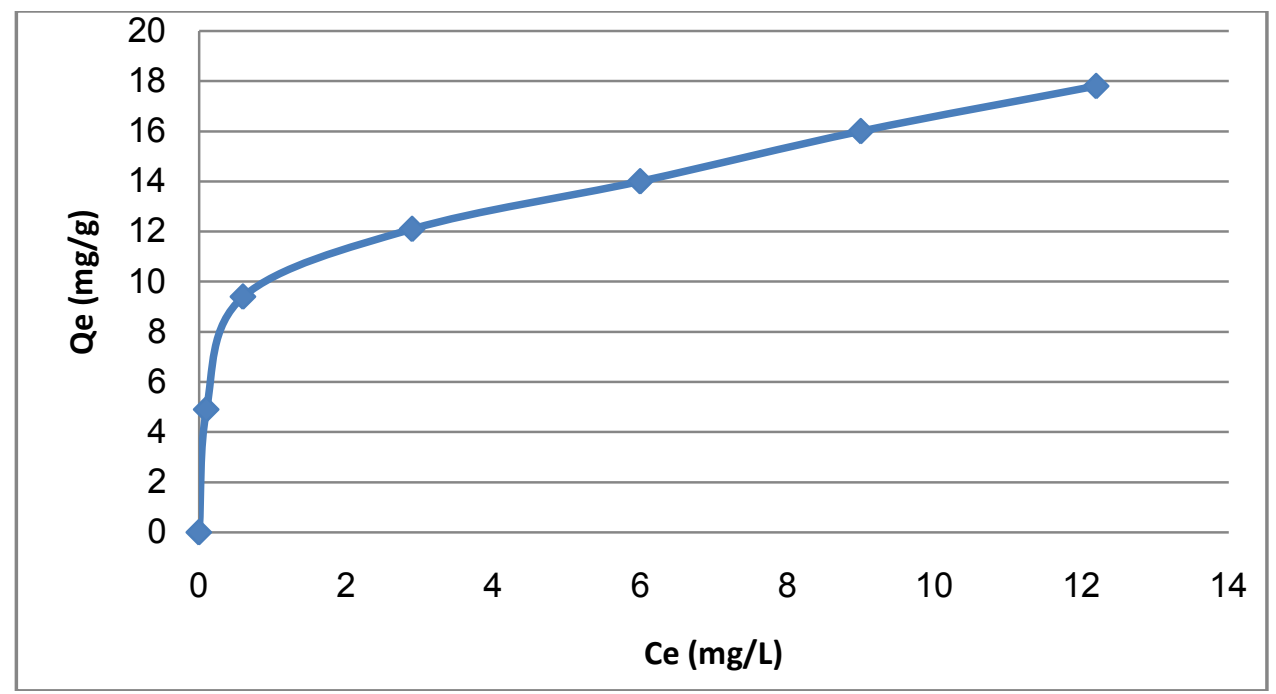

Fig. 6. adsorption isotherms for methyl violate dye for the Iraqi limestone

Tow adsorption isotherms models were used: Langmuir, and Freundlich. Langmuir's isotherm model suggests that the uptake occurs on homogeneous surface by monolayer sorption without interaction between adsorbed ions. The linear form of Langmuir isotherm equation is represented by the following equation $\frac{\mathrm{Ce}}{\mathrm{Qe}}=\frac{1}{Q \max b}+\frac{1}{Q \max } C e$ 2

Where $Q \max$ is the maximum methyl violate uptake per unit mass of limestone $(\mathrm{mg} / \mathrm{g})$ related to adsorption capacity and $b$ is Langmuir constant $(\mathrm{L} / \mathrm{mol})$ related to energy of sorption.

Therefore, a plot of $C e / q e$ versus $C e$, gives a straight line of slope $1 / Q \max$ and intercept $1 /(Q \max b)$. 


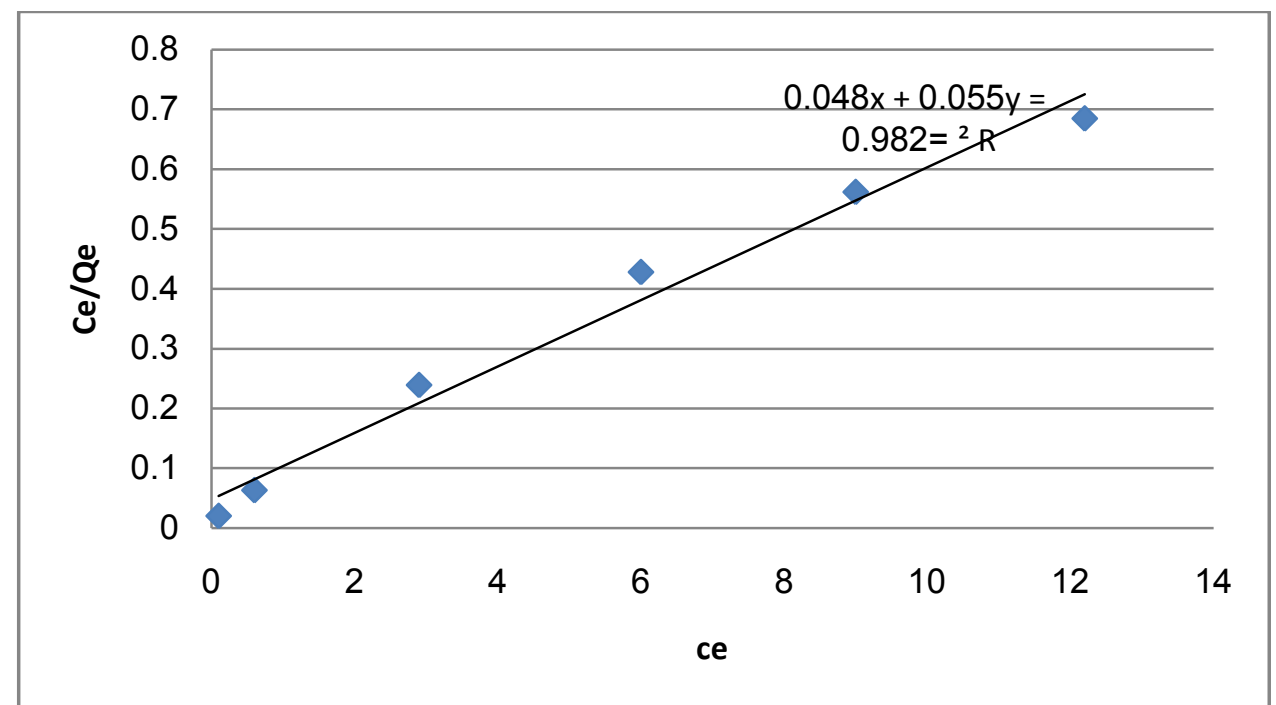

Fig. 7. shows the experimental data that were fitted by the linear form of Langmuir model, $(\mathrm{Ce} / \mathrm{Qe})$ versus $\mathrm{Ce}$.

line.

The values of $Q \max$ and $b$ were evaluated from the slope and intercept respectively for the isothermal

The Freundlich model is a case for heterogeneous surface energies and it gives an exponential distribution of active sites. The linear form of this model is represented by

$\ln Q \mathrm{e}=\ln K f+\frac{1}{n} \ln C e \quad 3$

The Freundlich constants $K f$ and $n$, which respectively indicating the adsorption capacity and the adsorption intensity, are calculated from the intercept and slope of plot ln $Q e$ versus $\ln C e$ respectively, as shown in Fig 8.

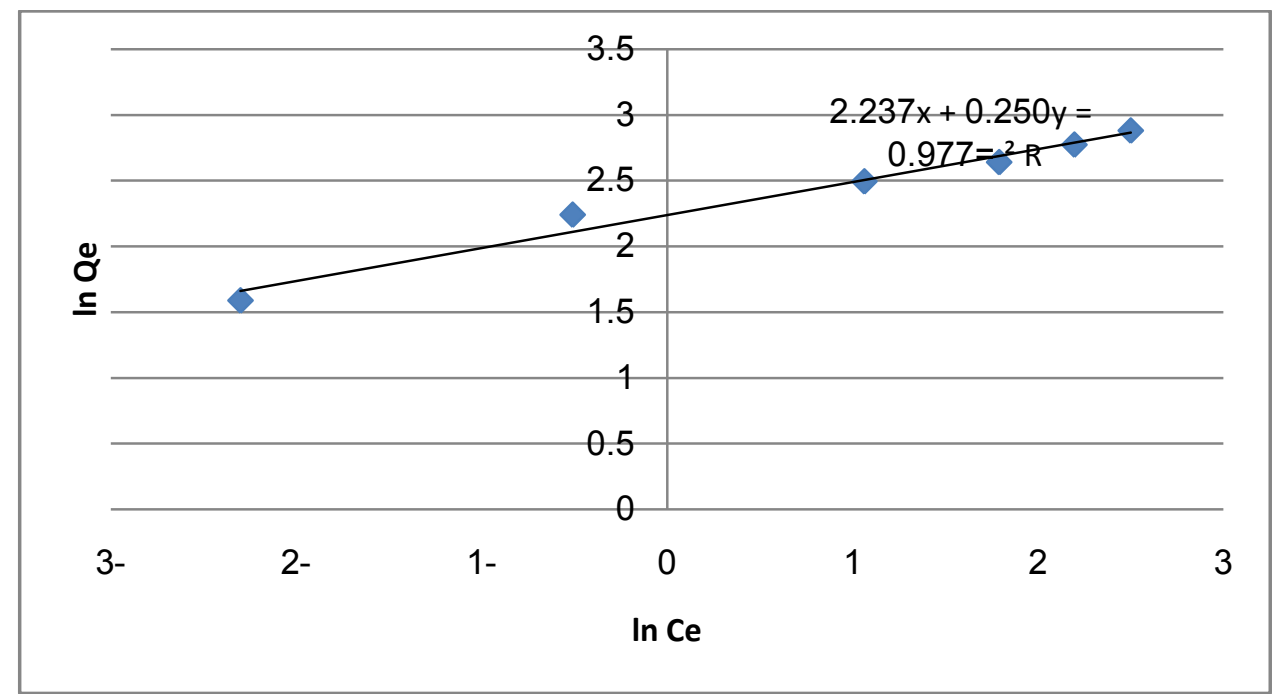

Fig. 8. shows the experimental data that were fitted by the linear form of Freundlich model, $\ln Q e$ versus $\operatorname{lnCe}$.

The goodness of fit of the experimental data is measured by the determination coefficients, $R^{2}$. At the Langmuir model showed better fit than Freundlich model.

\subsection{Temperature Effect and Thermodynamics Parameters}

The adsorption of methyl violate on Iraqi limestone at three different temperatures has been carried out. Variable temperature study will help in evaluating the basic thermo dynamical functions, $(\Delta \mathrm{H}, \Delta \mathrm{S}, \Delta \mathrm{G})$ of the adsorption processes.

Methyl violate adsorption decreases with increasing temperature, showing the exothermic nature of the process. The general shapes of adsorption are given in Fig. 9 The extent to which the methyl violate under study adsorption capacity decreases with increasing temperature might be attributed to the change in the surface 
properties of the adsorbent, solubility of the adsorbate species and exo-or endothermic nature of the adsorption process.

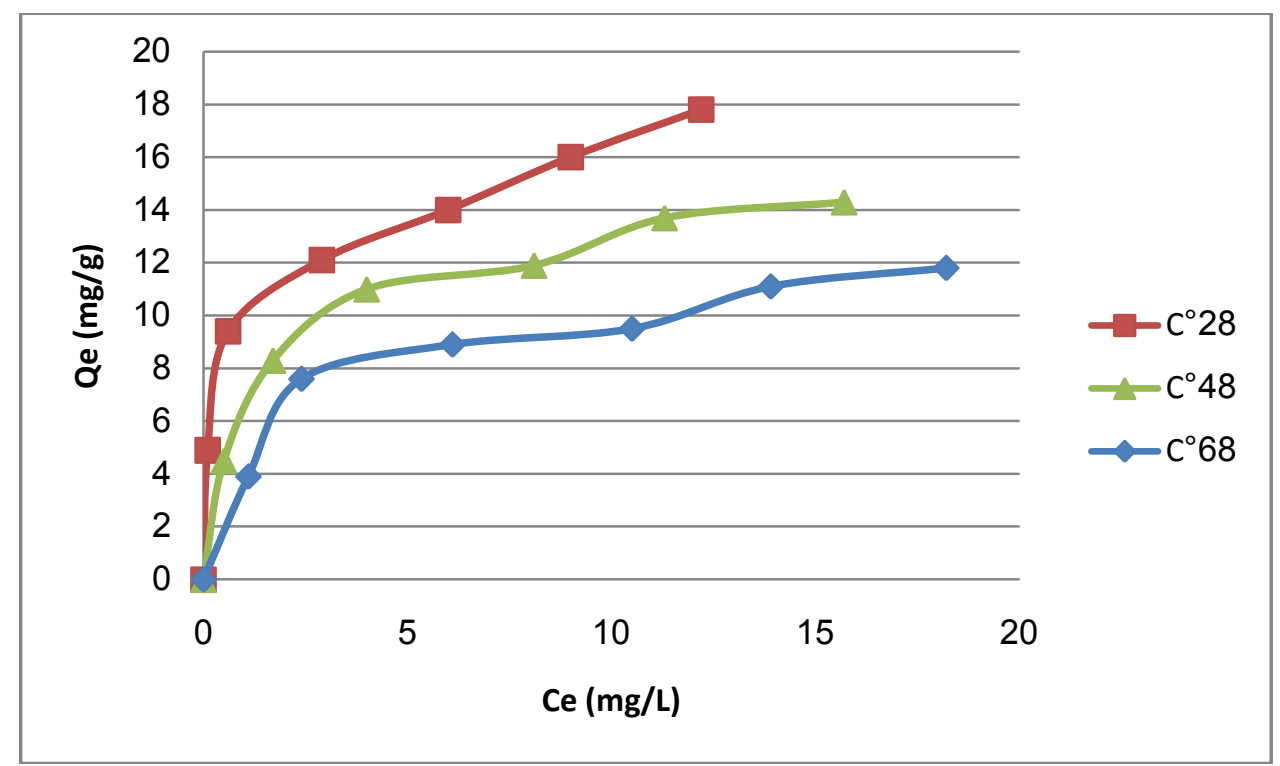

Fig. 9. adsorption isotherms of methyl violate dye on Iraqi limestone at different temperature

In order to determine thermodynamic parameters, experiments were carried out at three different temperatures $\left(28-68{ }^{\circ} \mathrm{C}\right)$. Using the following equations,

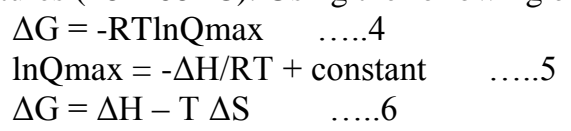

Where:

R:- is the ideal gas constant $(8.314 \mathrm{~J} / \mathrm{mol} . \mathrm{k})$

$\mathrm{T}$ :- is the absolute temperature

$\mathrm{K}$ :- is the equilibrium constant for the adsorption process at each temperature

Qmax:- is the maximum uptake of adsorption at a certain value of equilibrium concentration Ce that was fixed for all temperature of study.

The values of entropy change $\Delta \mathrm{S}$ and enthalpy change $\Delta \mathrm{H}$ can be calculated from the intercept and slope of the plot of ln Qmax vs. 1/T as shown in Fig. 10 all the parameters obtained from the plotted graph are tabulated in table 3 .

Table 3 Thermodynamic parameters of methyl violate

\begin{tabular}{|c|c|c|c|}
\hline \multirow{2}{*}{ Temperature $(\mathrm{K})$} & \multicolumn{3}{|c|}{ Thermodynamic parameters } \\
\cline { 2 - 4 } & $\Delta \mathrm{G}(\mathrm{kJ} / \mathrm{mol})$ & $\Delta \mathrm{S}(\mathrm{kJ} / \mathrm{mol} \mathrm{k})$ & $\Delta \mathrm{H}(\mathrm{kJ} / \mathrm{mol})$ \\
\hline 301 & -18.232 & 29.58 & -8.762 \\
321 & -18.186 & & \\
341 & -18.355 & & \\
\hline
\end{tabular}




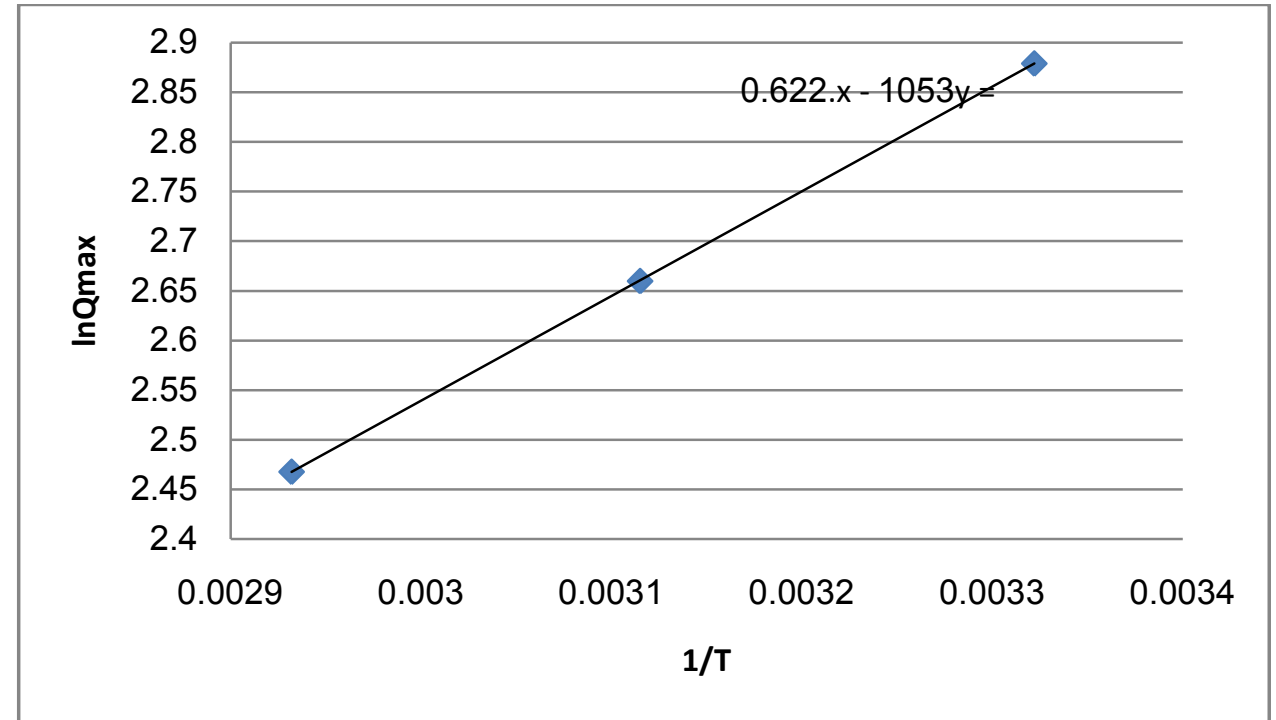

Fig. 11. Plot of lnQmax vs. $1 / T$ for estimation of thermodynamic parameters

The negative $\Delta \mathrm{G}$ value obtained from the equation 11 confirmed that the feasibility of the adsorption process and the spontaneous nature of the adsorption. Negative value of $\Delta H$ indicates the exothermic nature of the process. This is also confirms the possibility of physical adsorption as with the increase in temperature of the system [30]. Moreover, the positive value of $\Delta S$ corresponds to a increase in degree of freedom of the adsorbed species.

\subsection{Kinetics study}

The kinetic results obtained from batch experiments were analyzed using different kinetics models such as Lagergren pseudo first-order [35], pseudo second-order [36] models. Equation 12 gives the linear form of Lagergren pseudo first-order models

$1 / \mathrm{Q}_{\mathrm{t}}=\mathrm{Qe}+\mathrm{K} 11 / \mathrm{t} \quad 12$

Where $Q t$ is methyl violate concentration adsorbed on limestone at any time (mg of methyl violate/g of limestone) and $\mathrm{K} 1$ is the adsorption rate constant (min-1). A linear plot of $1 / Q_{t}$ against $1 / t$ gives the slope $=k 1$ and intercept $=\mathrm{Q} e$.

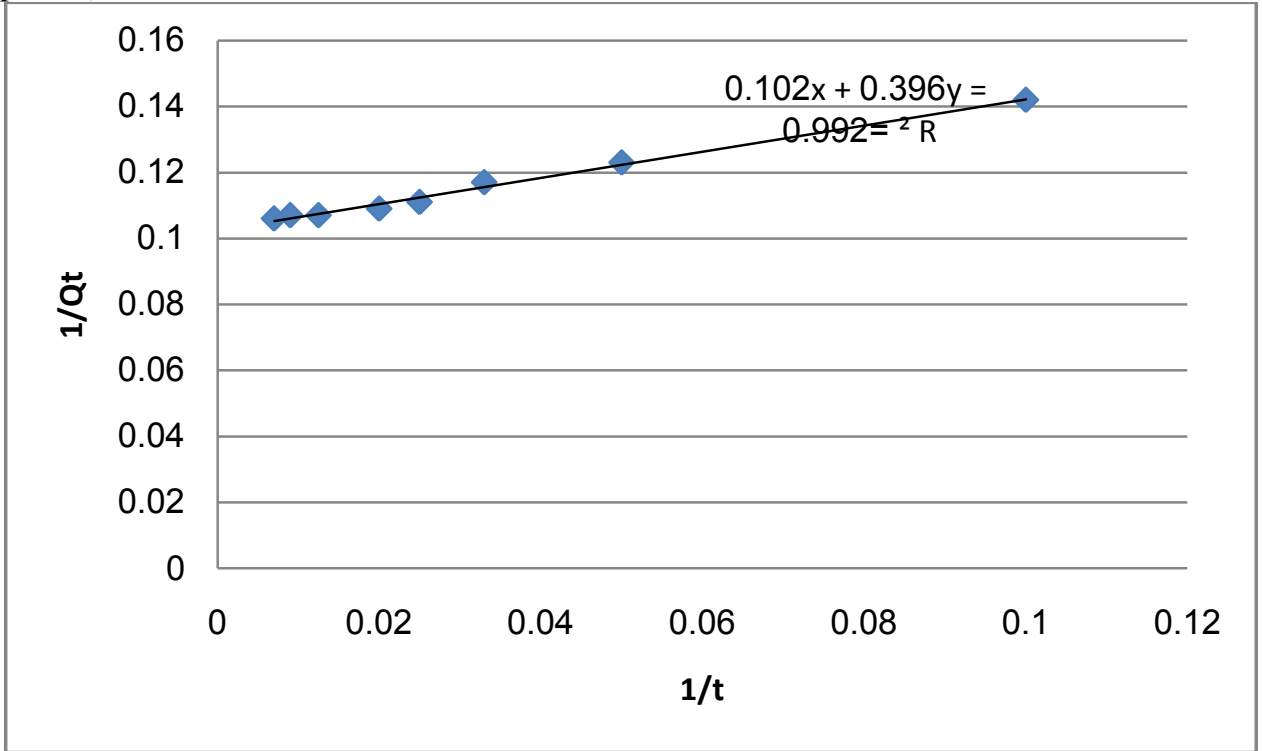

Fig. 12. Pseudo-first-order kinetic plots for the adsorption of methyl violate on limestone.

The equation that describes the pseudo-second order model is given in the following linear form $\frac{t}{Q t}=Q e+K 2 t$ 13

Where $K 2$ is the adsorption rate constant (g/mg-min). The $K 2$ and 
$Q e$ are found from the intercept and slop of $t / Q t$ versus $t$ linear plot such that $Q e=$ intercept and $k 2=$ slope.

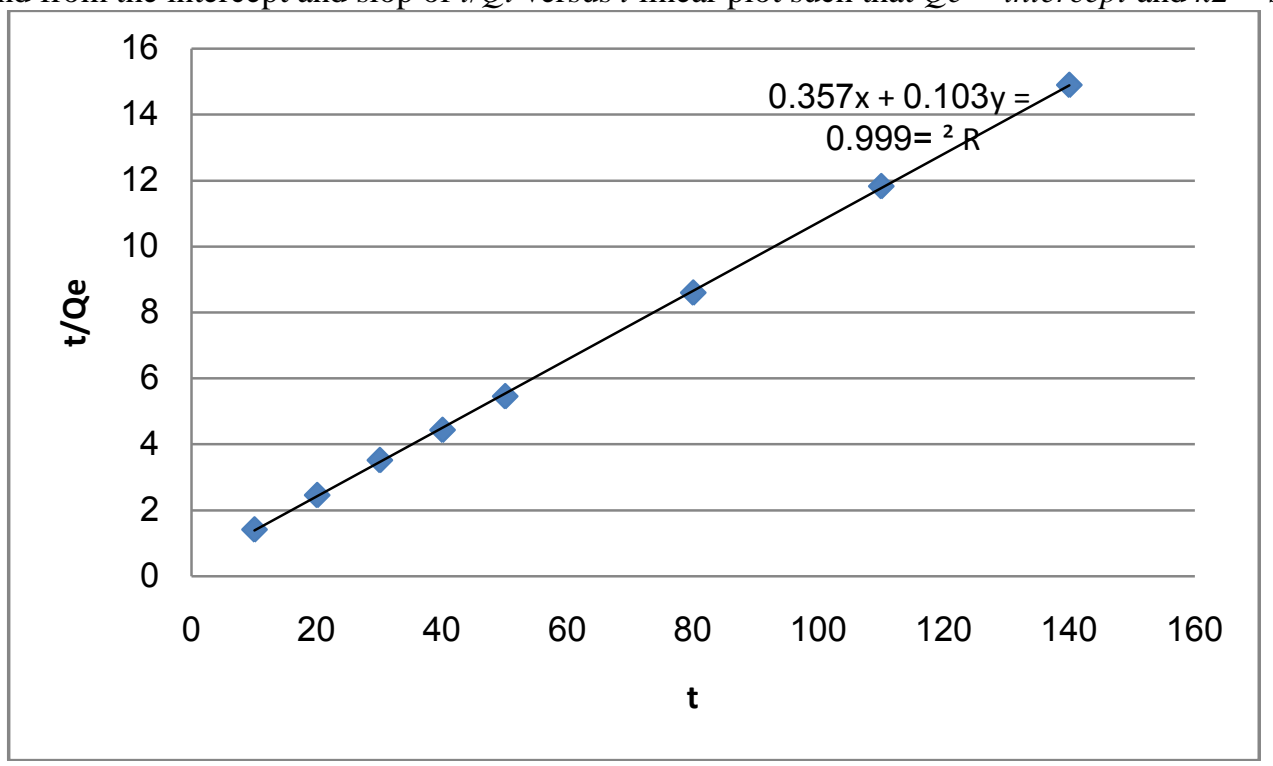

Fig. 13. Pseudo-second-order kinetic plots for the adsorption of methyl violate on limestone.

Table 4. The adsorption kinetic model rate constants for adsorption of Methyl violate on limestone.

\begin{tabular}{|l|l|l|l|l|l|}
\hline \multicolumn{4}{|l|}{ Pseudo first-order } & \multicolumn{3}{|l|}{ Pseudo second-order } \\
\hline K1 & Qe & $\mathrm{R}^{2}$ & $\mathrm{~K} 2$ & $\mathrm{Qe}$ & $\mathrm{R}^{2}$ \\
\hline 0.3965 & 0.1025 & 0.9923 & 0.1037 & 0.3579 & 0.9999 \\
\hline
\end{tabular}

$K 1$ in (1/min), $K 2$ in (g/mg-min), Qe in (mg/g ).

The degree of goodness of linear plot of these kinetic models can be judged from the value of the determination coefficient of the plot, which can also be regarded as a criterion in the determination of the adequacy of kinetic model.

From the determination coefficient $\left(\mathrm{R}^{2}\right)$ and adsorption quantity $(\mathrm{Qe})$ values above, adsorption of methyl violate on the limestone is regarded as pseudo-second order rather than pseudo-first-order.

\section{Conclusions}

Based upon the experimental results of this study, the following conclusions can be drawn:

1. The maximum removal efficiency of methyl violate occurs at $75 \mu \mathrm{m}$ particle size, $\mathrm{pH}=10$ and solution temperature $28^{\circ} \mathrm{C}$.

2. The removal efficiency of methyl violate increases as the dosage of the adsorbent increases.

3. The isotherm study indicates that the Freundlich and Langmuir isotherms models can adequately model sorption data.

4. The equilibrium removal of methyl violate decreases as the temperature of solution increases.

5. The removal of methyl violate by this limestone is an exothermic process.

6. It is found that the pseudo-second order model is applicable for whole the range of contact time while not for the pseudo-first order

\section{Acknowledgments} the samples.

Thanks go to the Directorate of Laboratories in Chemical Engineering Dep / AL-Nahrain University for analyzing

\section{References}

[1] Strivastava, K.A., Gupta, S.K., and Iyer, M.V.S., “Colour Removal from Paper Mill Waste”, J. of Inst. Public Health Eng. India, Part 2/3, 1984, 59-64.

[2] McKay, G., Oterburn M.S. and Aga, D.A., "Fullers Earth and Fired Clay as Adsorbent for Dye Stuffs, Equilibrium and Rate Constants", Water. Air, soil Pollut., 24, 1985, 307-322.

[3] Gregory, A.R., Elliot, S Kluge. and P. Ames., "Testing of Direct Black 3Bparallel Carcinogenicity” J. Appl. Toxicol 1, 1991, 308313.

[4] Stringheta, Identificacao da estrutura e estudo da estabilidade das antocianinas extraidas da inflorescencia de capim gordura (Mellinis minutuflora, Pal de Beauv.). Tese, UNICAMP, Campinas-SP, P. C. 1991.

[5] Geankoplis, C. J., Transport Process and unit operations, Prentice-Hall. pp. 1993, 697-707.

[6] B. Chen, C.W. Hui, G. McKay, Pore-surface diffusion modeling for dyes from effluent on pith, Langmuir 17, 2001, 740-748. 
[7] L. Markovska, V. Meshko, V. Noveski, M. Marinovski, Solid diffusion control of the adsorption of basic dyes onto granular activated carbon and natural zeolite in fixed bed columns, J. Serbian Chem. Soc. 66, 2001, 463-475.

[8] G. Crini, Bioresource Technology, 97, 2006, 1061.

[9] F.-C. Wu, R.-L. Tseng. and R.-S. Juang, Journal of Hazardous Materials, 69, 1999, 287.

[10] R. Dolphen, N. Sakkayawong, P. Thiravetyan. and W. Nakbanpote, Journal of Hazardous Materials, 145, 2007, 250.

[11] G. Annadurai, L. Y. Ling. and J. F. Lee, Journal of Hazardous Materials, 152, $2008,337$.

[12] M. Dogan, M. Alkan, A. Turkyilmaz. and Y. Ozdemir, Journal of Hazardous Materials, 109, 2004, 141.

[13] P. Liu and L. Zhang, Separation and Purification Technology, 58, 2007, 32.

[14] T. B. Iyim and G. Guclu, Desalination, 249, 2009, 1377.

[15] G. McKay, M. El Geundi. and M. M. Nassar, Process Safety and Environmental Protection, 74, 1996, 277.

[16] J. X. Lin, S. L. Zhan, M. H. Fang, X. Q. Qian. and H. Yang, Journal of Environmental Management, 87, 2008, 193.

[17] N. Dizge, C. Aydiner, E. Demirbas, M. Kobya and S. Kara, Journal of Hazardous Materials, 150, $2008,737$.

[18] S. Jain and R. V. Jayaram, Desalination, 250, 2010, 921.

[19] A. L. Ahmad, M. M. Loh and J. A. Aziz, Dyes and Pigments, 75, 2007, 263.

[20] Y. Guo, S. Yang, W. Fu, J. Qi, R. Li, Z. Wang and H. Xu, Dyes and Pigments, 56, 2003, 219.

[21] V. K. C. Lee, J. F. Porter and G. McKay, Food and Bioproducts Processing, 79, $2001,21$.

[22] Q. Sun and L. Yang, Water Research, 37, 2003, 1535.

[23] Habeeb G .M, "Use of Crushed Limestone from Bahr Al-Najaf as an Aggregate for Concrete" Al Najaf Technical Institute, 1990.

[24] Cement Public Company, "hydrological Investigation", Danish Geotechnical Institute and Iraq Cement Public Company Report, 1960.

[25] Dai, M., J. Colloid Interface Sci. 164, 1994, 223-228.

[26] J.M. Smith, Chemical Engineering Kinetics, McGraw-Hill, New York, 1970.

[27] Lafferty, C., Hobday, M., Fuel 69, 1990, 78-83.

[28] Do gan, M., Ph.D. Thesis, Department of Chemistry, Balıkesir University, Balıkesir, Turkey (in Turkish), 2001.

[29] Alkan, M., Do_gan, M., Perlite Surfaces, Encyclopedia of Surface and Colloid Science, Marcel Dekker, New York, pp. 2002, 3945-3958.

[30] Mall, I.D., Srivastava, W. and K, Argawal., "Removal of orange G and Methyl Violet Dyes by Adsorption Onto Bagasse Fly AshKinetic Study and Equilibrium Isotherm Analyses", Dyes and Pigments, 69, 2006, 210-223.

[31] Lagergren, S. Zur Theorie der sogenannten Adsorption gelöster Stoffe. Kungliga Svenska Vetenskapsakademiens Handlingar, Vol. 24, 1898, 1-39.

[32] Ho, Y. S.; McKay, G. Process Biochem. 34, 1999, 451-465. 